\title{
Print-Capture PCR for Detection of Tomato Begomoviruses from Plants and Whiteflies
}

\author{
Tatsuya Nagata ${ }^{1}$, Alice K. Inoue-Nagata ${ }^{2}$, Antonio C. de Ávila ${ }^{3} \&$ Leonardo de B. Giordano ${ }^{4}$ \\ 1Pós-graduação em Biotecnologia Genômica, Universidade Católica de Brasília, Campus II, SGAN 916, CEP 70790-160, Brasília, \\ DF, fax (61) 347-4797, e-mail: tatsuya@pos.ucb.br; ${ }^{2}$ Departamento de Biotecnologia; ${ }^{3}$ Departamento de Virologia; \\ ${ }^{4}$ Departamento de melhoramento, Embrapa Hortaliças, Cx. Postal 0218, CEP 70359-970, Brasília, DF
}

(Aceito para publicação em 18/08/2003)

Corresponding author: Tatsuya Nagata

NAGATA, T., INOUE-NAGATA, A.K., DE ÁVILA, A.C. \& GIORDANO, L.B. Print-capture PCR for detection of tomato begomoviruses from plants and whiteflies. Fitopatologia Brasileira 29:091-093. 2004.

\begin{abstract}
Print-capture (PC) Polymerase chain reaction (PCR) was evaluated as a novel detection method of plant viruses. Tomato (Lycopersicon esculentum) plants infected with begomovirus (fam. Geminiviridae, gen. Begomovirus) and viruliferous whiteflies were used to study the efficiency of the method. Print-capturing steps were carried out using non-charged nylon membrane or filter paper as the solid support for DNA printings. Amplified DNA fragments of expected size were consistently obtained by PCR from infected plants grown in a greenhouse, after direct application of printed materials to the PCR mix. However, virus detection from a single whitefly and

\section{RESUMO}

Deteç̧ão de begomovírus de tomateiro em plantas e moscasbrancas por "print-capture" PCR

$\mathrm{O}$ "print-capture (PC) Polymerase chain reaction (PCR)" foi avaliado como um método inovativo de detecção de vírus de plantas. Plantas de tomate (Lycopersicon esculentum) infetadas com begomovírus e moscas-brancas virulíferas foram usadas para estudar a eficiência do método. Os passos de captura do DNA foram realizados usando filtros de náilon não carregados ou papel-filtro como suporte sólido. Fragmentos de DNA amplificados de tamanho esperado foram consistentemente obtidos por PCR de plantas infetadas cultivadas em casa de vegetação, após aplicação direta dos

from field-grown tomato samples required a high temperature treatment of printed material prior to PCR amplification. Comparison of nylon membrane and filter paper as the solid support revealed the higher efficiency of the nylon membrane. The application of printcapture PCR reduces the chances of false-positive amplification by reducing manipulation steps during preparation of the target DNA. This method maintains all the advantages of PCR diagnosis, such as the high sensitivity and no requirement of radioactive reagents. argentifoli.

materiais fixados na mistura para PCR. Entretanto, para a detecção de vírus feita de uma mosca-branca e de amostras de tomateiros cultivados no campo foi necessário um tratamento a alta temperatura do material fixado antes da amplificação por PCR. Na comparação entre o filtro de náilon e papel-filtro como suporte sólido, o filtro de náilon apresentou maior eficiência de detecção. A aplicação do PC PCR reduz as chances de ocorrência de resultados falsospositivos pela diminuição de passos de manipulação durante a preparação do DNA-alvo. Este método mantém todas as vantagens da diagnose por PCR, como a alta sensibilidade sem a necessidade de uso de reagentes radioativos.
\end{abstract}

A disease complex of tomato (Lycopersicon esculentum Mill.) caused by begomoviruses (fam. Geminiviridae, gen. Begomovirus) has become a serious problem in tropical and subtropical countries. The viruses are known to be vectored by whiteflies (Bemisia tabaci Gennadius). The major symptoms caused by begomoviruses in tomato are yellow mosaic, mottling, rugosity, stunting and fruit set reduction.

The first reported incidence of tomato begomovirus in Brazil was the Tomato golden mosaic virus (TGMV) in the early 1960's (Flores et al., 1960). However, major outbreaks of begomoviruses in this crop have only been observed during the last decade (Giordano et al., 1996). The occurrence of begomoviruses in Central Brazil was reported in 1994 in the Federal District, showing an infection rate of 40 to $100 \%$ in some tomato fields (Bezerra et al., 1996). In 1996, in the State of
Minas Gerais, $50 \%$ of tomato plants in the field appeared to be infected with two distinct species of begomovirus (Rezende $e t$ al., 1996; Zerbini et al., 1996). In the São Francisco Valley, a complete loss of the tomato crop was observed in many areas in 1997 (Bezerra et al., 1997). Begomovirus characterization and resistance breeding programs are undergoing in several research institutions in Brazil and around the world.

The most common method of begomovirus detection currently in use is probably hybridization with radioactive isotopes, mainly $\left[\mathrm{P}^{32}\right]$. The use of radioactive materials requires heavy laboratorial infrastructure and well-trained professionals. An additional limitation of this methodology is the short life of the probes made with $\left[\mathrm{P}^{32}\right]$. Non-radioactive virus detection using Polymerase chain reaction (PCR) offers the advantage of high sensitivity. However, this method is highly labor 
intensive mainly during the preparation of target DNA, making its application difficult for large-scale detection. Print-capture (PC) PCR was evaluated as a practical method for begomovirus detection to be used in diagnostic, epidemiological and breeding programs.

A begomovirus isolate, named "Distrito Federal M isolate" (DFM) [partial genome sequence showed high homology to Tomato mottle leaf curl virus (TMLCV)] was used to test the print-capture method. The virus isolate was maintained on tomato plants by whitefly transmission using viruliferous colonies released in a whitefly-proof cage under greenhouse condition.

Stems of tomato plants infected with the DFM isolate were cut with a sterile razor blade and the cut edge was printed onto a nylon membrane (Atzmon et al., 1998) or filter paper (Navas-Castillo, et al., 1998) in several spots. After drying the green spots, the printed material was cut into small pieces of approximately $0.5 \mathrm{~mm}^{2}$ and only one piece was processed directly on PCR without undergoing any purification procedure. Two materials were compared as print support, a filter paper (Whatmann 3MM) and a non-charged nylon membrane (Hybond N, Amersham-Pharmacia). The filter paper was previously sterilized in an autoclave. The nylon membrane was used directly without any sterilization.

Tomato leaves showing typical begomovirus symptoms were collected from commercial fields. The leaves were crushed in $0.4 \mathrm{~N} \mathrm{NaOH}$ (diluted 1:10) and spotted onto a nylon membrane (Hybond $\mathrm{N}+$, Amersham-Pharmacia). The membrane was immersed in $1 \mathrm{M}$ Tris ( $\mathrm{pH} 7.4$ ) and $0.5 \mathrm{~N} \mathrm{NaCl}$ for $5 \mathrm{~min}$ for neutralization and then in ethanol $95 \%$ for 5 min to eliminate the green color from the spots. After drying, the membrane was hybridized as described for Southern blot hybridization.

Viruliferous whitefly was also prepared using a similar protocol. A single whitefly was sandwiched with two pieces of nylon membrane or filter paper and immediately crushed with the aid of a glass tube. Therefore, two pieces of printed material were obtained from a single insect. One piece of printed whitefly sample was added to a PCR mix without adding Taq DNA polymerase. For PC-PCR of the whitefly preparation, Taq DNA polymerase was added after treatment of the PCR mix with the sample submitted at the temperature of $95{ }^{\circ} \mathrm{C}$ for $10 \mathrm{~min}$, followed immediately by the conventional PCR. The second piece was added to a complete PCR mix and processed normally.

Two PCR primers were designed to amplify the entire coding region of the coat protein $(\mathrm{CP})$ of the DFM isolate: $\mathrm{CP} 1$ (5'-ATGYCTAAGMGKGAKGCCCC-3') and CP2 (5'-AACTTC CAAGTCTGGACG-3'). The obtained fragment of approximately $0.9 \mathrm{Kbp}$ included the start codon of the $\mathrm{CP}$ gene up to about two hundred nucleotides downstream of the stop codon. The PCR was performed in 40 cycles of $94^{\circ} \mathrm{C}(1 \mathrm{~min})-55^{\circ} \mathrm{C}(1 \mathrm{~min})-$ $72{ }^{\circ} \mathrm{C}$ ( $\left.2 \mathrm{~min}\right)$, following incubation of $72^{\circ} \mathrm{C}$ for $5 \mathrm{~min}$. After amplification, the PCR products were electrophoresed in a $1 \%$ agarose gel to visualize the amplified DNA.

The specificity of the amplified DNA fragments was confirmed by Southern blot hybridization. The amplified DNA fragments migrated in an agarose gel were denatured by immersing in $1.5 \mathrm{M} \mathrm{NaCl}$ and $0.5 \mathrm{~N} \mathrm{NaOH}$, and then neutralized in $1 \mathrm{M}$ Tris (pH 7.4) and $1.5 \mathrm{M} \mathrm{NaCl}$ before capillary transfer to a nylon membrane (Hybond $\mathrm{N}+$, Amersham-Pharmacia). The membrane was then washed with $5 \mathrm{x}$ SSC for $1 \mathrm{~min}$. The hybridization procedure was done using non-radioactive probes labeled with dUTP-Digoxigenin (Inoue-Nagata et al., in preparation). Hybridization was done at $68^{\circ} \mathrm{C}$ using a standard hybridization buffer $[5 \mathrm{x}$ SSC, $0.1 \% \mathrm{~N}$ lauroylsarcosine, $0.02 \%$ SDS, $1 \%$ blocking agent (Boehringer Mannheim)] and the washing steps at the same temperature using low salt SSC (twice with $2 \mathrm{x}$ SSC, $0.1 \%$ SDS and twice with $0.5 x$ SSC, $0.1 \%$ SDS) was applied. Hybridized DNA with digoxigenin-labelled probes was detected using antidigoxigenin antibodies conjugated with alkaline phosphatase. The substrates, nitro blue tetrazolium (NBT) and bromo-chloroindolyl phosphate (BCIP) were applied to visualize the specific bands as a purple precipitate.

The greenhouse grown plant material was tested without any treatment prior to PCR. A single amplified DNA fragment was recognized only in infected materials and it had the expected size of $0.9 \mathrm{Kbp}$ (Figure 1). Both filter paper and nylon membrane were successfully used as a solid support for printing (Figure 1, lanes 2,4). The nylon membrane showed a better result for amplification when plant materials were used. No bands were observed in the negative controls (non-infected plants) or water control (data not shown). The specificity of the reaction was confirmed by Southern blot hybridization (data not shown).

Two treatments were tested for PC-PCR from a single whitefly. The first protocol used the printed whiteflies in a direct way without any treatment prior to PCR. In the second protocol, the printed material was heat treated at $95^{\circ} \mathrm{C}$ for 10 min. The PCR amplification was not successful when whitefly samples were not heat treated before PCR (data not shown). It is possible that the activity of the Taq DNA polymerase was inhibited by the substances present in the insect. To circumvent this problem, the printed samples were heat-treated in the PCR mix before adding the Taq DNA polymerase. After cooling to

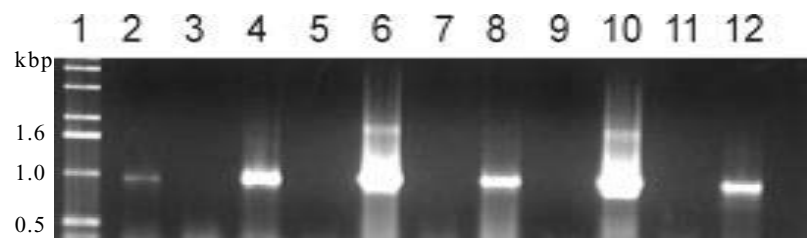

FIG 1 - Comparison between filter paper and nylon membrane as the solid support for print-capture PCR from "Distrito Federal M isolate" (DFM) infected tomato (Lycopersicon esculentum) and whitefly (Bemisia tabaci). 1: Size marker (1 Kb ladder, GIBCO-BRL); 2, 4: DFM infected tomato; 3, 5: non-infected tomato; 6, 8: viruliferous whitefly; 7, 9: non-viruliferous whitefly. Lanes $2,3,6$, 7: whatmann filter paper; lanes 4, 5, 8, 9: nylon membrane. 10: Purified total DNA from DFM infected tomato; 11: Negative control (water); 12: Cloned DNA of Bean golden mosaic virus. 
Print-capture PCR for detection of tomato begomoviruses from...

room temperature, Taq DNA polymerase was added and PCR was carried out as described above. Taq DNA polymerase was added only after the heat treatment to avoid possible reduction of the enzymatic activity by potential inhibitors and by prolonged incubation under high temperature. The heat treatment resulted in successful amplification of begomovirus specific DNA using whitefly samples (Figure 1, lanes 6, 8). The specificity of the amplified DNA fragments was confirmed by Southern blot hybridization (data not shown).

The application of this method for begomovirus detection in field samples was also evaluated in comparison with other methods such as dot-blot hybridization (Figure 2, Dot-blot) and visual symptom diagnosis (Figure 2, Symptom). Ten tomato samples were collected in three different fields in the Federal District. Six plants showed begomovirus-like symptoms and four were symptomless. The hybridization method can be considered a reliable detection technique for begomoviruses. The diagnosis using PC-PCR provided the same results as dot-blot hybridization. Seven positives were obtained with samples analyzed with both dot-blot hybridization (Figure 2, Dot-blot) and PC-PCR [Figure 2, PC $(+\mathrm{HT})]$. However, PC-PCR without the heat treatment was less efficient [Figure 2, PC (-HT)] than the two former detection methods. Visual symptom diagnosis cannot be used as a precise method due to false positives, as other viruses or environmental factors can cause similar symptoms. The latent period of infection can also cause misleading results when evaluated by a visual criterion. PC-PCR is highly sensitive,

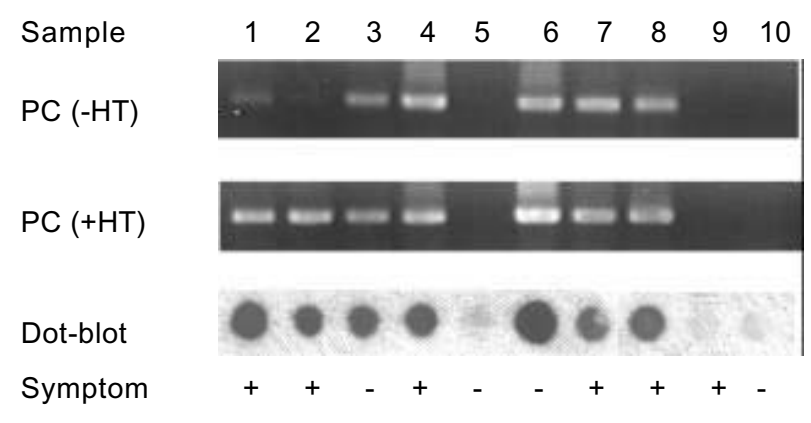

FIG. 2 - Comparison of four different methods of begomovirus detection from field tomato (Lycopersicon esculentum) samples. PC $(-\mathrm{HT})$, print-capture PCR without heat treatment; PC $(+\mathrm{HT})$, printcapture PCR with heat treatment; dot-blot, dot-blot hybridization; Symptom, presence $(+)$ or absence (-) of begomovirus-like symptoms as evaluated in the field. convenient and more reliable than the conventional PCR procedure because print capturing steps reduce the risks of cross-contamination during preparation of target samples. Therefore, this method can be an effective tool for screening tomato plants for resistance to begomovirus.

Selection of the primer pairs seems to be crucial for diagnostic purposes. Since only small number of field samples were tested for this study, the use of this primer pair for diagnostic purposes should be evaluated with larger number of genetic variants of begomoviruses.

\section{LITERATURE CITED}

ATZMON, G., VAN OSS, H. \& CZOSNEK, H. PCR-amplification of tomato yellow leaf curl virus (TYLCV) DNA from squashes of plants and whitefly vectors: Application to the study of TYLCV acquisition and transmission. European Journal of Plant Pathology 104:189-194. 1998.

BEZERRA, I.C., RIBEIRO, S.G., DE ÁVILA, A.C. \& GIORDANO, L.B. Survey of geminivirus infection in tomato producing areas in Federal District. VIII Encontro Nacional de Virologia. Abstract V16, p. 289. São Lourenço-MG. 1996. p.289.

BEZERRA, I.C., LIMA, M.F., RIBEIRO, S.G., GIORDANO, L.B. \& DE ÁVILA, A.C. Occurrence of Geminivirus in Tomato Producing Areas in Submédio São Francisco. Fitopatologia Brasileira 22:331. 1997. (Resumo)

FLORES, E., SILBERSCHMIDT, K. \& KRAMER, M. Observações de clonese infecciosa das malváceas em tomateiros do campo. Biológico 26:65-69. 1960

GIORDANO, L.B., BEZERRA, I.C., RIBEIRO, S.G. \& ÁVILA, A.C. Breeding tomatoes (Lycopersicon esculentum Mill.) for resistance to whitefly-transmitted geminiviruses. Preceedings, $1^{\text {st }}$ International Conference on the Processing Tomato, Recife, PE, 1996. pp.164166.

NAVAS-CASTILLO, J., DIAZ J.A., SANCHEZ-CAMPOS, S. \& MORIONES, E. Improvement of the print-capture polymerase chain reaction procedure for efficient amplification of DNA virus genomes from plants and insect vectors. Journal of Virological Methods 75:195198. 1998 .

REZENDE, E.A., FILGUEIRA, F.A.R., ZERBINI, F.M., ZAMBOLIM, E.M., FERNANDES, J.J. \& GILBERTSON, R.L. Tomato Infected with Geminivirus in Greenhouse Conditions at Uberlândia-MG, Brazil. Fitopatologia Brasileira 21:424. 1996. (Resumo)

ZERBINI, F.M., ZAMBOLIM, E.M., FERNANDES, J.J., GILBERTSON, R.L. \& CARRIJO, I.V. Geminivírus isolado de tomateiro (Lycopersicon esculentum L.). Fitopatologia Brasileira 21:430. 1996. (Resumo) 